\title{
Ichthyoplankton Distribution and Abundance off Southeastern and Southern Brazil
}

\author{
Débora Martins de Freitas and José Henrique Muelbert* \\ Departamento de Oceanografia; Fundação Universidade Federal do Rio Grande - FURG; C. P. 474; 96201-900; \\ docdmf@furg.br,docjhm@furg.br; Rio Grande - RS - Brazil
}

\begin{abstract}
This study describes the distribution of fish eggs and larvae along the southeastern and southern Brazilian coast. Plankton samples were collected at 85 stations using a Bongo net, and water salinity and temperature were profiled with a CTD. Results showed that fish eggs and larvae, and zooplankton biovolume were distributed in coastal waters with mean temperature of $23^{\circ} \mathrm{C}$ and salinity between 33 and 34 . The largest egg abundance occurred along Iguape $\left(24^{0} 36^{\prime} S\right)$ with a partial overlap with zooplankton biovolume and fish larvae were most abundant near shore close to Santos $\left(24^{0} S\right)$. These protected coastal waters presented a surface layer with lower salinity and higher temperatures, while the bottom layer had cooler water. Ichthyoplankton abundance was low off Cabo Frio $\left(22^{\circ} 30^{\prime} S\right)$, while a maximum in fish eggs occurred around Cabo Santa Marta Grande $\left(28^{0} S\right)$.
\end{abstract}

Key words: Ichthyoplankton, Southern Brazilian Continental Shelf, abundance, distribution

\section{INTRODUCTION}

The southeastern and southern continental shelf of Brazil is a region of complex interactions among physical, chemical and biological processes (Castello et al., 1990). Interaction between physical and biological processes has been shown at the level of phytoplankton (Odebrecht and Djurfeldt, 1996), zooplankton (Resgalla and Montú, 1993), ichthyoplankton (Muelbert and Sinque, 1996; Sinque et al., 1996), and fishery resource level (Andrade, 1996).

The importance of physical processes for the ecology of fish eggs and larvae is evident in the studies conducted in this region. The distribution pattern of bluefish larvae (Pomatomus saltatrix), for example, is influenced by the dynamic of the Brazil current (Muelbert and Sinque, 1996), and different groups of fish larvae are associated to different oceanographic processes (Muelbert and Sinque, 1995; Sinque et al., 1996). The spawning and life cycle of the Brazilian sardine (Sardinella brasiliensis) and anchovy (Engraulis anchoita) depend on the intensity of the penetration of Sub-tropical waters over the bottom of the continental shelf, and on the formation of retention areas and/or stability of the water column (Matsuura and Kitahara, 1995). Due to the importance of the interaction between physical and biological processes, specific studies on this subject have been recommended for a better understanding of recruitment variability in fisheries resources (Hunter and Alheit, 1997), and for an enhancement in the knowledge of life cycles of fish species through the determination of their spawning location and period (Hempel, 1973).

In the study region, ichthyoplankton distribution is influenced by the dynamic of the Subtropical

\footnotetext{
* Author for correspondence
} 
Convergence, by freshwater inflow from the Patos Lagoon and Rio de la Plata, by the inland drainage of Santos and the estuarine complex of IguapeCananéia and Paranaguá, and by wind action on the surface of the ocean. This paper describes the distribution of fish eggs and larvae between Cabo Frio (22 $30^{\prime} \mathrm{S}$ ) and Cabo Santa Marta Grande $\left(28^{0} \mathrm{~S}\right)$ from November 15 to December 5, 1995.

\section{MATERIAL AND METHODS}

Ichthyoplankton samples were taken from 85 stations with average distance of 20 nautical miles (Fig. 1) using a $60 \mathrm{~cm}$ diameter, $300 \mu \mathrm{m}$ mesh Bongo net equipped with a flowmeter.

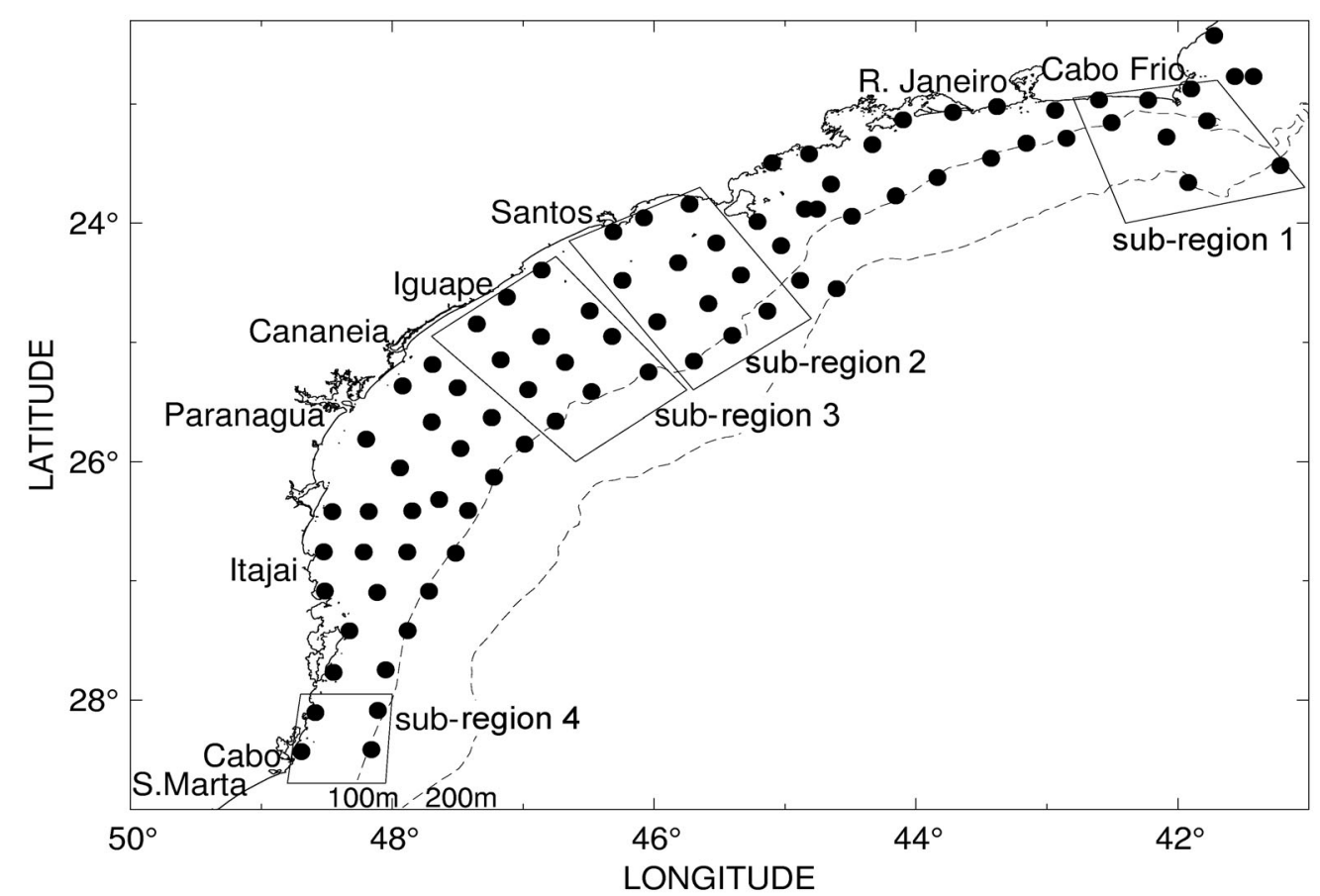

Figure 1 - Distribution of sampling stations along the study region for the period between 11/15 and 12/05/1995. Boxes encompass the sub-regions selected to characterize the physical structure of areas with higher ichthyoplankton abundance and upwelling conditions.

Water salinity and temperature were obtained at each station with a Seabird 19 CTD. Samples were taken with oblique hauls from $5 \mathrm{~m}$ above the bottom, or at deeper waters from $200 \mathrm{~m}$ depth. Ship speed was held at 2 knots. One side of the Bongo net was used for ichthyoplankton material and was fixed with $4 \%$ formalin buffered with Borax. The other side was used for biovolume analyses and was conserved in 70\% alcohol.

At the laboratory, fish eggs and larvae were sorted and counted with the help of a stereoscopic microscope. After sorting, ichthyoplankton concentration was determined and expressed as organisms per $100 \mathrm{~m}^{3}$ of filtered water $\left(\mathrm{n} / 100 \mathrm{~m}^{3}\right)$.
Zooplankton biomass was estimated as displacement volume $\left(\mathrm{ml} / 100 \mathrm{~m}^{3}\right)$ after removal gelatinous organisms (Omori and Ikeda, 1992).

Maps of the horizontal distribution of fish eggs and larvae, zooplankton biovolume, salinity and temperature were made using GRI graphic package (Kelley, 1997). All surface salinity and temperature maps refer to data collected at $10 \mathrm{~m}$ depths. Contour maps were made using the objective analyses method with a grid of 0.5 degrees latitude by 0.6 degrees longitude. Vertical profiles of water salinity, temperature and density $\left(\sigma_{t}\right)$ were drawn using the same method with a grid of 1.8 by $7.5 \mathrm{~m}$. These graphs were combined to 
characterize the oceanographic conditions of the areas with highest ichthyoplankton abundance and food availability for larval fish. The study region was sub-divided in four sub-regions according to the spatial distribution of ichthyoplankton and the presence of coastal upwelling. These sub-regions were analyzed by transects from the coastal zone to the $100 \mathrm{~m}$ depth isobaths.

\section{RESULTS AND DISCUSSION}

\section{1) Environmental setting}

The northern portion of the study region, off Cabo Frio $\left(22^{0} 30^{\prime} \mathrm{S}\right)$, is characterized by a narrow continental shelf (Castro and Miranda, 1998) where a coastal upwelling is revealed by an isolated center of cold waters with $22^{\circ} \mathrm{C}$ and 35.5 salinity. This upwelling is extended from Cabo Frio to Rio de Janeiro $\left(23^{0} \mathrm{~S}\right)$ (Fig. 2).

The water column in this region showed densities around $<25$ closer to the shore and around 26 further offshore below the $60 \mathrm{~m}$ isobaths. Coastal salinity values were around 35 , and 36.5 offshore below $40 \mathrm{~m}$ depth. The thermal structure of the region varied between 16 and $24^{\circ} \mathrm{C}$, with a maximum to the east of Cabo Frio associated to waters of salinity values higher than 36 (Fig. 3).

These values indicated the influence of Tropical Water (TW) transported by the Brazil Current (BC) (Miranda and Katsuragawa, 1991). In this narrow shelf region, an isolated center of cold waters $\left(<19^{\circ} \mathrm{C}\right)$ at $10 \mathrm{~m}$, allowed the identification of waters with the TS characteristics of the South Atlantic Central Water (SACW) (Miranda and Katsuragawa, 1991). At $25 \mathrm{~m}$, the area of influence of the SACW was larger and temperatures were around $16^{\circ} \mathrm{C}$.

It is also possible to verify the existence of a Coastal Water $(\mathrm{CW})$ mass with warmer $\left(23^{\circ} \mathrm{C}\right)$ and less saline (around 35) waters (Miranda and Katsuragawa, 1991) (Fig. 3).

In the central part of the study area, the shelf reaches its maximum width of approximately 230 $\mathrm{km}$ (Castro and Miranda, 1998). In this area, surface water temperature was homogeneous and around $24^{\circ} \mathrm{C}$ at $10 \mathrm{~m}$ depth, while salinity gradient was observed towards the ocean (Fig. 2). Vertically, the physical structure of the waters of these region presented low densities between 22 and 24 closer to the coast, and between 25 and 26 near the shelf edge (Figs. 4 and 5).

Salinity also showed lower values in the coastal region, between 33 and 34, and values between 35 and 36 towards the ocean. Highest salinity values were found further offshore when compared with the northern portion of the study region (Figs. 3, 4 and 5). This gradient could be attributed to the increase in coastal runoff to the shelf in the Santos region (Castro et al., 1987). Coastal temperature values remained between 23 and $24^{\circ} \mathrm{C}$ closer to the surface, but reached $18^{\circ} \mathrm{C}$ in the lower layers. This indicated the presence of a thermocline in the coastal region off Santos (Figs. 4 and 5). In the southern portion of the study region, between Itajaí $\left(27^{0} \mathrm{~S}\right)$ and Cabo Santa Marta Grande $\left(29^{\circ} \mathrm{S}\right)$, the continental shelf gradually narrows (Castro and Miranda, 1998) allowing the influence of the SACW in the area. This could be identified by low temperature $\left(<21^{\circ} \mathrm{C}\right)$ and salinity higher than 34 closer to the shore (Fig. 2). This region was periodically subjected to coastal upwelling (Katsuragawa and Matsuura, 1992). Water column was characterized by higher density values in the coastal region, between 24.5 and 25 , a low density lens at about $30-80 \mathrm{~km}$ from the coast, and a further density increase towards the shelf edge. Salinity also is higher, being around 35.5 closer to the shore. Temperature was closer to $19^{\circ} \mathrm{C}$ at $10 \mathrm{~m}$ depth, indicating the existence of a cooler water mass penetrating towards the coast at depth (Fig. 6).

According to Matsuura (1986), the cold water found in the coastal region around the island of Florianópolis $\left(27^{0} 36^{\prime} \mathrm{S}\right)$ was originated from offshore, but the mechanism of its transport is poorly understood. The presence of SACW in the bottom layers in this region seemed to be important factor to the development of a breeding habitat for the sardine and an important source for nutrients to the photic zone (Matsuura, 1986). 

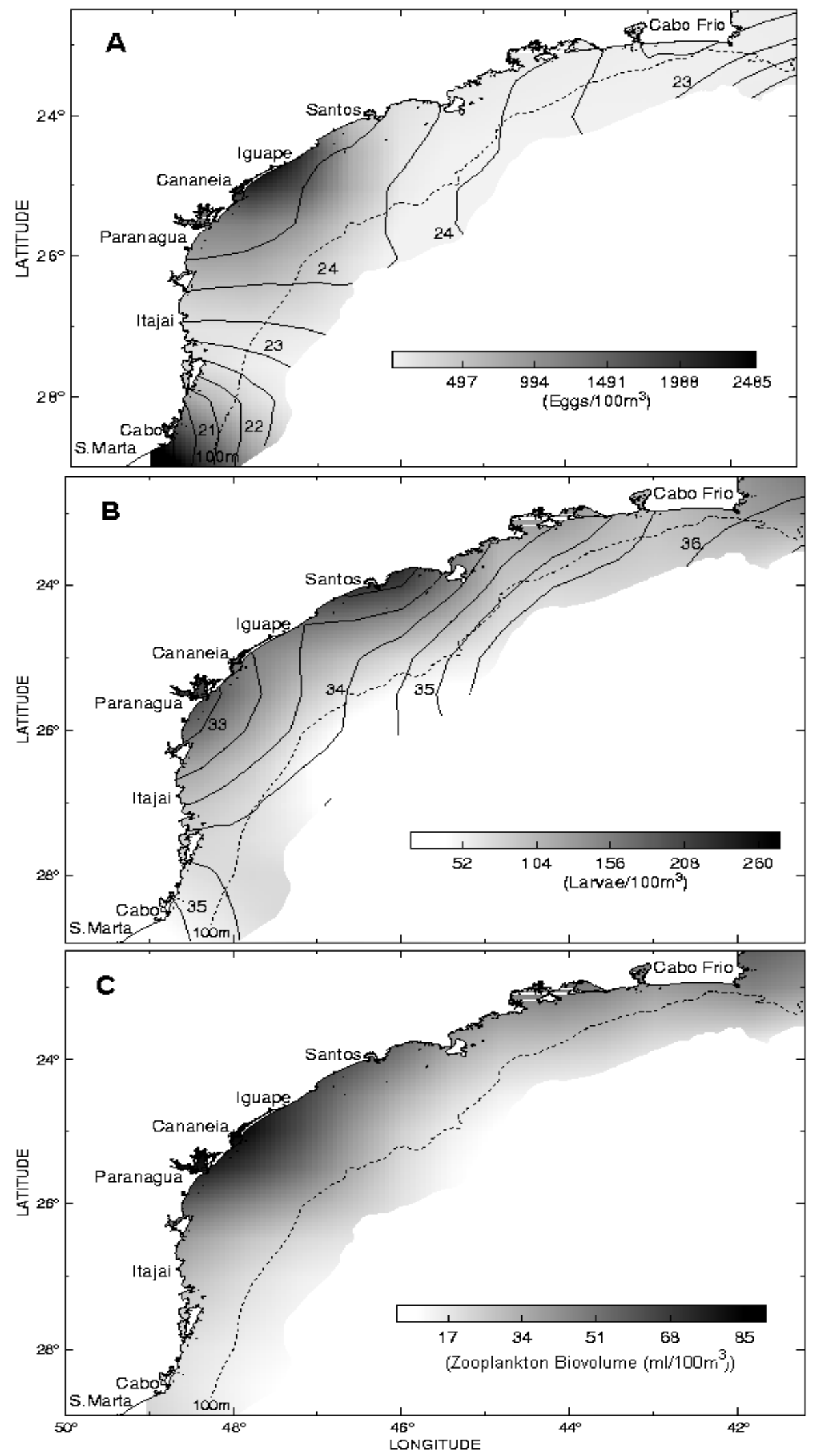

Figure 2 - A. Spatial distribution of fish eggs and temperature isolines $\left({ }^{0} \mathrm{C}\right)$. B. Spatial distribution of fish larvae and salinity isolines. C. Spatial distribution of zooplankton biovolume $\left(\mathrm{ml} / 100 \mathrm{~m}^{3}\right)$, between $11 / 15$ and $12 / 05 / 95$. 

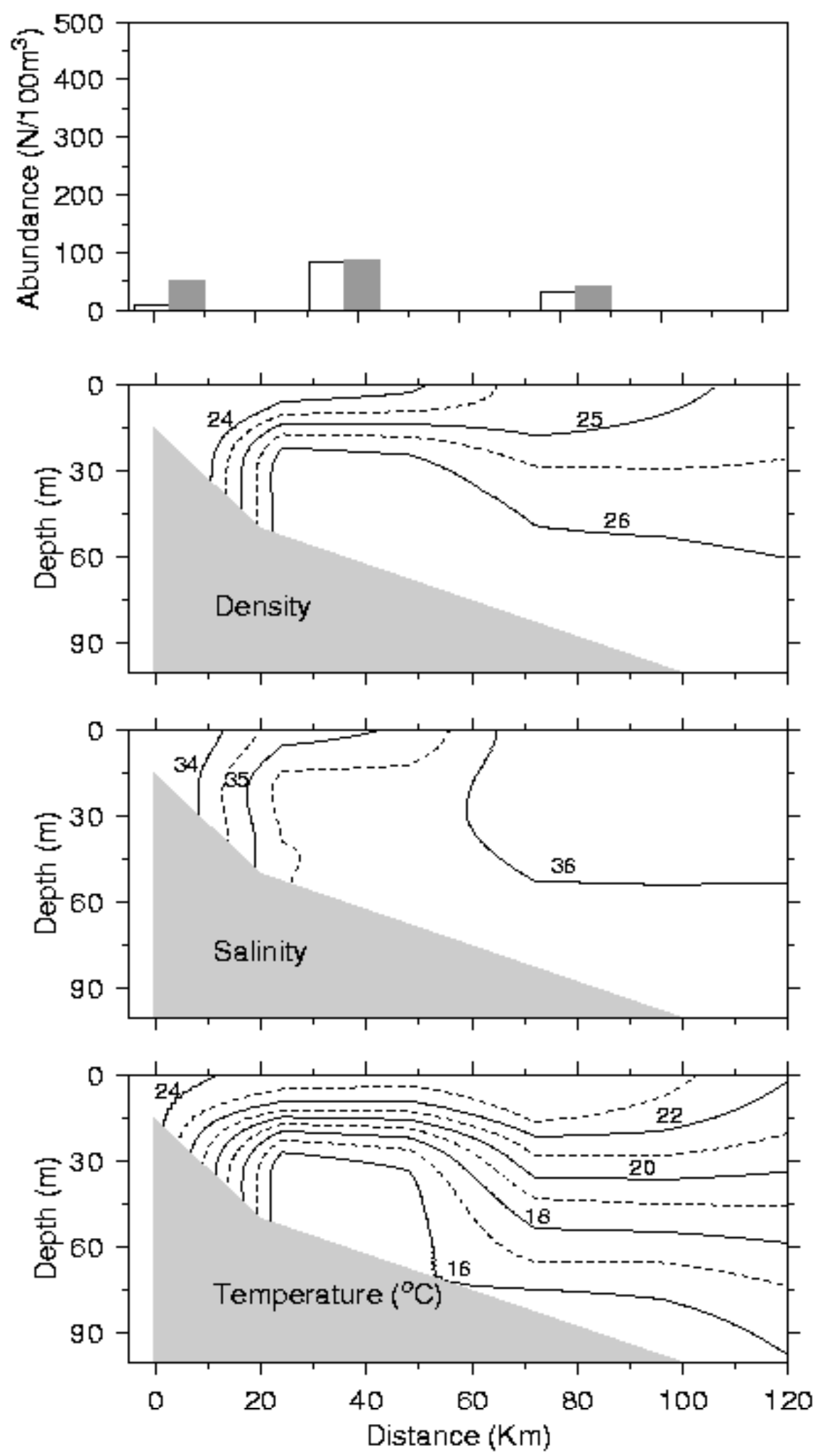

Figure 3 - Physical structure in vertical section (from coast to $200 \mathrm{~m}$ isobaths) of the sub-region 1 (Cabo Frio). Fish eggs ( $\left.\square-n / 100 m^{3}\right)$ and larvae $\left(\square-n / 100 m^{3}\right)$ abundance. 
2) Ichthyoplankton distribution and oceanographic conditions: stratification and upwelling areas

The largest concentration of fish larvae and eggs (Figs. 4 and 5) were found in sub-region 2 and 3, respectively, while zooplankton biovolume (Fig. 2c) was most abundant in sub-region 3 (Fig. 1). These were coastal protected areas with low water density (22 to 24 ) and salinity (33 and 34), and temperatures around $24^{\circ} \mathrm{C}$ (Figs. 4 and 5). Caution should be taken when comparing our study with previously published results in the region, since we report ichthyoplankton abundance as per $\mathrm{m}^{3}$ while most studies in the region used number per $\mathrm{m}^{2}$. Despite this fact, Matsuura (1979) found that the principal spawning ground and the area with highest fish larvae abundance in the coastal region of São Paulo was located in regions with mean water temperature of $24^{\circ} \mathrm{C}$ and average salinities of 34.5. Results of the ichthyoplankton distribution indicated spawning activity of coastal fish species that inhabith these areas. Coastal regions adjacent to estuaries (estuarine complex of IguapeCananéia and Paranaguá) presented favorable conditions for the development of fish species that used these areas as nursery and protection for their eggs and larvae (Soares et al., 1991).

The largest concentration of eggs and larvae occurred between Santos and Paranaguá (Figs. 2a and $\mathrm{b}$ ). In this region, the SACW was displaced away from the coast towards the $100 \mathrm{~m}$ isobaths when compared to the northern portion of our study area, where the ichthyoplankton concentration was smaller (Figs. 2a and b, 3). This displacement allowed for the upwelling of less thermally stratified waters $\left(18<\mathrm{T}<23^{\circ} \mathrm{C}\right)$ with a deeper mixing zone close to the coast. In the vicinity of Santos, a gradual shift in the thermal structure was observed with an intensification of the seasonal thermocline. However, isolated centers of cold water remained in the bottom of the continental shelf (Figs. 4 and 5). In this area, at approximately $25^{\circ} \mathrm{S}$, Castello et al. (1991) found concentrations of sardine and anchovy (Engraulis anchoita), whose distribution and reproduction was related to the thermal structure of the water column (Matsuura, 1986).

A zone of stability in the water column could be observed as a result of the penetration of the cooler SACW over the shelf (Figs. 4 and 5). Spawning during this period would yield to the larvae an environment protected from turbulent mixing by the vertical stability (Lasker, 1975). A stable ocean is known to be favorable for larval development. Furthermore, the weakening of Ekman transport in the coastal regions associated to the closed geostrophic circulation pattern of the Bight prevents fish eggs and larvae to be advected offshore (Bakun and Parrish, 1990).

In this region, anchovy shared the pelagic environment with the sardine, identified as one of the most important Brazilian fishery resource (Matsuura, 1986). During spring and summer months, NE wind driven upwelling allows the development of a favorable environment to the development of the larval stages of both species. Preliminary identification of fish larvae collected in this study indicated the presence of a great number of Engraulidae and Clupeidae, followed in abundance by Sciaenidae and Pleuronectidade.

Cabo Frio and Cabo Santa Marta Grande are coastal areas subjected to wind induced upwelling (Katsuragawa and Matsuura, 1992; Odebrecht and Djurfeldt, 1996), and where the lowest concentration of fish eggs and larvae, and zooplankton biovolume occured (Fig. 2). However, a maximum of egg abundance was observed at Cabo de Santa Marta Grande (Figs. 2a and 6), where Matsuura (1998) found intense spawing of sardine down to the $100 \mathrm{~m}$ isobath. The weak upwelling observed during the study period (Fig. 6) could be associated with this high concentration of fish eggs.

Cury and Roy (1989) applying non-linear methods to analyze some fish species distribution, among them the Peruvian anchovy and the Californian sardine, obtained a relationship between reproductive success and wind intensity in upwelling regions. They found that reproductive success of fish was high with moderate intensity wind, and that it decreased with higher and lower intensities of wind. According to these authors, the existence of an "optimal environmental window" in cases of moderate upwelling is the result of the balance between two parameters (reproductive success of fish and intensity of wind) where the organisms would encounter favorable conditions for their development.

It is known that several fish species have their reproductive strategies adjusted for environmental factors such as surface currents (Parrish et a1., 1981). Meteorological and oceanographic conditions influence the feeding of organisms, and currents can transport eggs and larvae. 

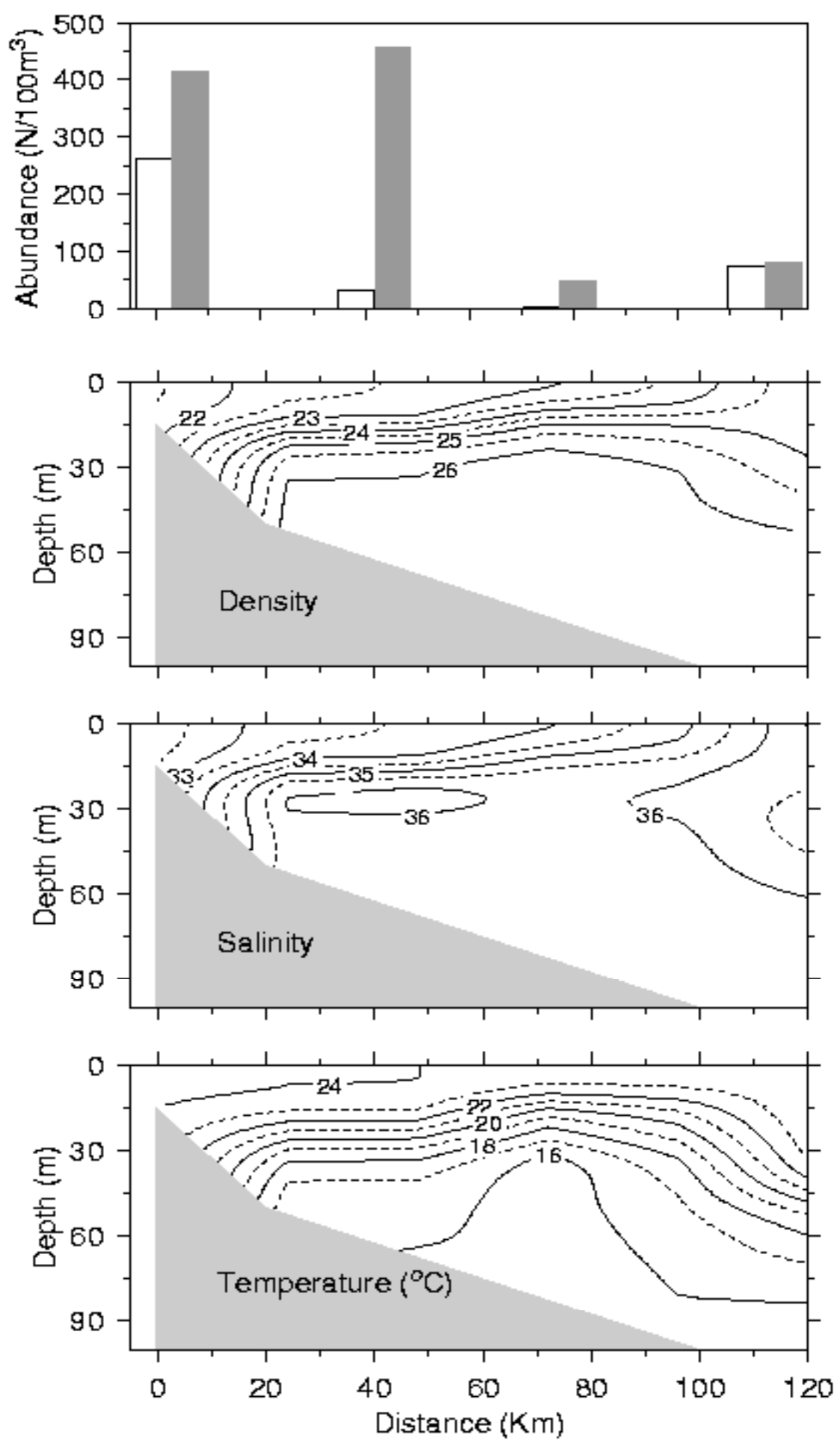

Figure 4 - Physical structure in vertical section (from coast to $200 \mathrm{~m}$ isobaths) of the sub-region 2 (Santos-São Sebastião). Fish eggs $\left(\square-n / 100 m^{3}\right)$ and larvae $\left(\square-n / 100 m^{3}\right)$ abundance. 

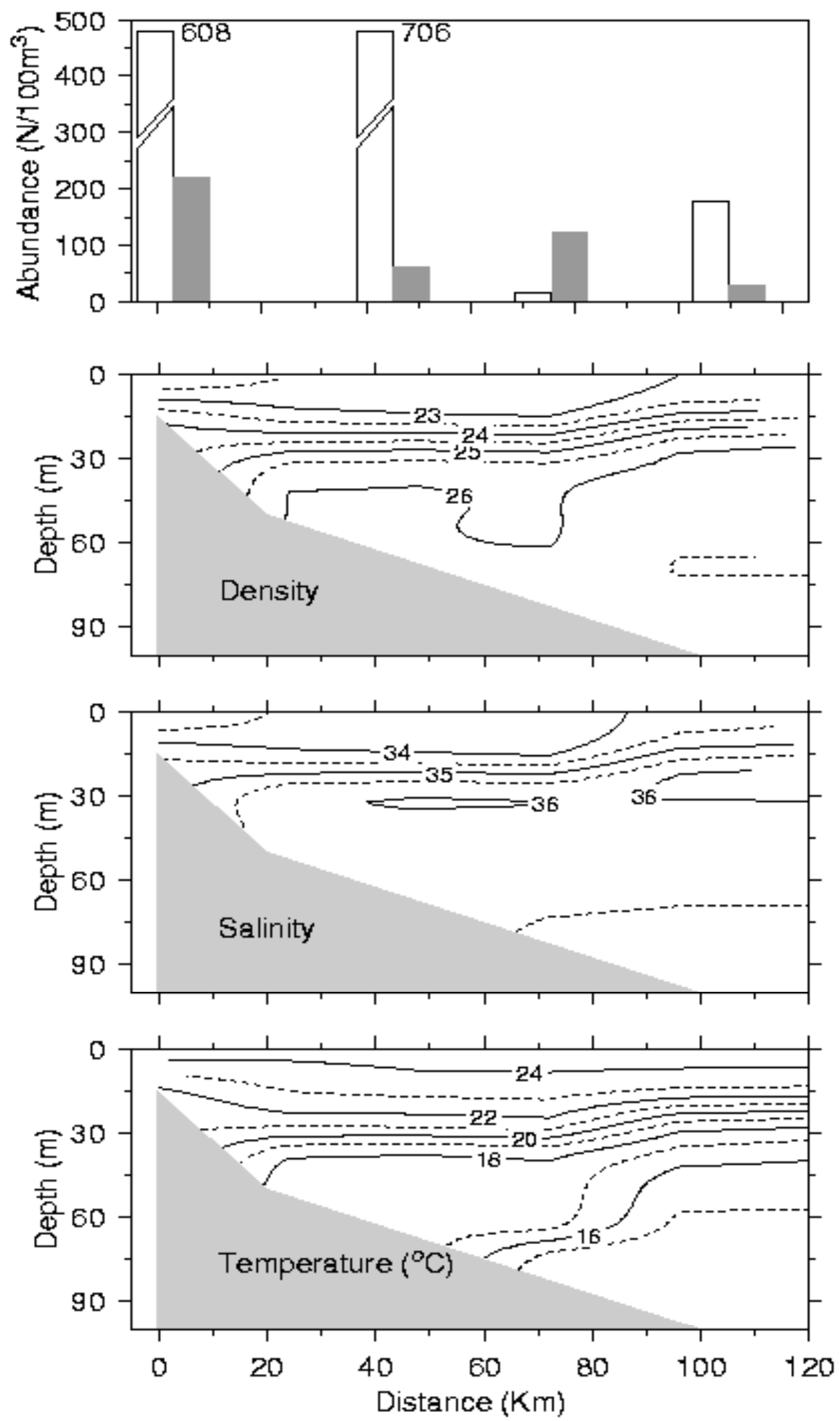

Figure 5 - Physical structure in vertical section (from coast to $200 \mathrm{~m}$ isobaths) of the sub-region 3 (Iguape) Fish eggs $\left(\square-n / 100 m^{3}\right)$ and larvae $\left(\square-n / 100 m^{3}\right)$ abundance. 

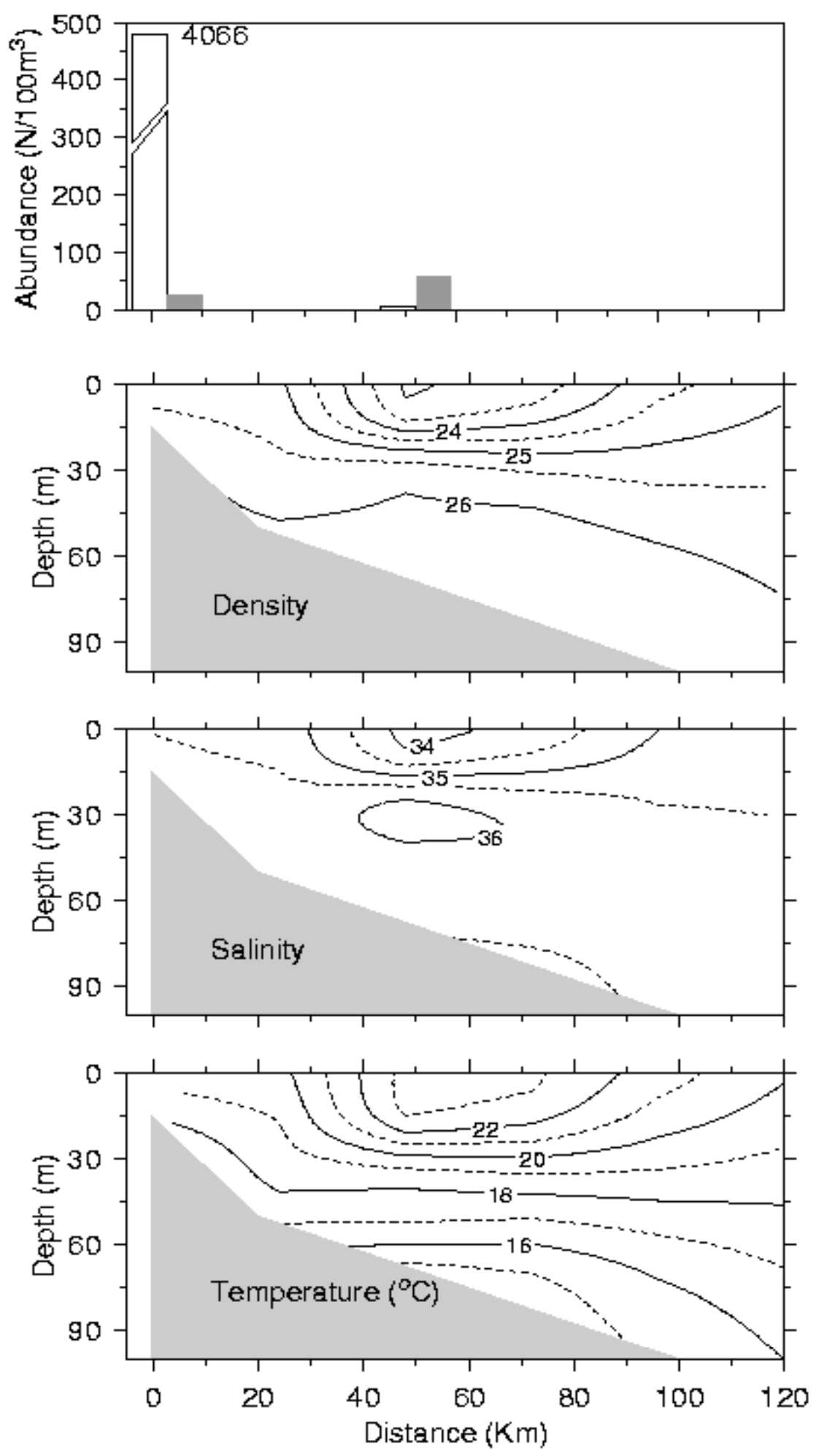

Figure 6 - Physical structure in vertical section (from coast to $200 \mathrm{~m}$ isobaths) of the sub-region 4 (Cabo de Santa Marta Grande) Fish eggs $\left(\square-\mathrm{n} / 100 \mathrm{~m}^{3}\right)$ and larvae $\left(\square-\mathrm{n} / 100 \mathrm{~m}^{3}\right)$ abundance. 
As a result, the reproductive success of fish is affected resulting in recruitment variability. According to Parrish et a1. (1981), in the northwest Pacific several coastal species that have larval pelagic stages have a tendency to spawn during the winter, when wind stress over the sea surface transports their offspring directly into the coastal region.

If spawning would occur during the strong upwelling season, larvae would be carried offshore. They have also noticed that few species spawn off northern California, where upwelling is strongest, thus avoiding rapid transport of their eggs and larvae to less productive regions away from the coast. Probably the high spawning event observed off Cabo de Santa Marta Grande is related to an event of moderate upwelling.

\section{3) Partial overlaping between fish eggs and zooplankton and interdependency between fish larvae and zooplankton}

The results of our study indicate that the largest zooplankton biovolume also occurred in coastal waters (Fig. 2c), with water temperatures around $24^{\circ} \mathrm{C}$ and salinities between 33 and 34 . Katsuragawa et al. (1993) suggested that the high densities observed for total zooplankton in this region were associated to strongest penetration of the SACW during summer. This could be verified in our study at transects located in sub-regions 2 and 3 (Figs. 4 and 5). However, these sub-regions were also under the influence of freshwater (Figs. 4 and 5). Matsuura et al. (1980) attributed this coastal enhancement of zooplankton density to the association between seasonal warming of surface waters and freshwater output from the Santos region and the estuarine complex of IguapeCananéia and Paranaguá. These results suggest that high zooplankton concentrations were related to an inter-play between penetration of SACW and estuarine input.

According to Cushing (1997), zooplanktonic organism represents the main source of food for larvae and juvenile marine pelagic fish like sardines (Sardinella brasilienses). Therefore, an overlap between ichthyoplankton distribution and that of zooplankton is expected.

The partial overlap between the distribution of zooplankton biovolume and fish eggs suggests a sinchrony between spawning and food availability for the future larvae. This synchrony between ichthyo and zooplankton has already been observed by Katsuragawa et al. (1993). They also observed a tendency for a spatial segregation between the abundance of zooplankton and larval fish, which we have found in our study (Figs. 2b and c).

Many studies have reported the independence between the spatial and temporal distribution of fish larvae and zooplankton. According to Frank (1988), the most common problem associated to plankton studies was the use of adequate mesh size to sample fish larvae and their prey. In general, larvae smaller than $10 \mathrm{~mm}$ preyed on plankton organisms smaller than $200 \mu \mathrm{m}$ (Theilacker, 1980). However, mesh sizes used to collect ichthyoplankton generally exceed $200 \mu \mathrm{m}$. The use of zooplankton information obtained in these cases to study fish larvae feeding has to take into account the fact that zooplankton of larger size is retained in coarser mesh. It is necessary to distinguish between natural and sampling artifacts before making inferences on the ecological implications of such findings. In our study we used a $300 \mu \mathrm{m}$ mesh net and, therefore, did not make inferences regarding larval feeding. However, zooplankton abundance may be used as an important indicator of oceanographic processes and biological secondary production.

Sinclair and Iles (1985) enphasized the importance of physical oceanographic processes on biological interactions to explain this distinguished pattern of spatial distribution. According to these authors, feeding conditions in areas of larval distribution are of secundary importance to the survival, and that larval retention in geographically stable areas is the most important factor regulating the sucess of the reproductive unit. They report the existence of many defined areas of spawing and larval distribution for herring in poorer well-mixed waters compared to the richer, highly productive, stratified waters during summer. These authors concluded that the spawning and larval distribution areas are a function of the location of physical characteristics associated to larval retention. It is not infered that larvae are passivelly retained by the circulation of the area, but that this would be attributed to an active behavioural response to the physical regime. They also concluded that the maintenance of an aggregated larval population may be essential to the reproductive success in the establishment of a viable population, since that larvae that are lost from this aggregation are unable to recruit to the stock. The weak offshore Ekman transport in the 
interior regions of the Bight associated to a closed geostrophic circulation (Bakun and Parrish, 1990) allow the suggestion that spawning in this coastal region would be favorable to the reproductive success of fish species inhabing the southeastern and southern continental shelf of Brazil.

\section{CONCLUSIONS AND SUGGESTIONS}

- The largest concentration of fish eggs and larvae were found in coastal protected waters with low density (22-24) and salinity (33-34) values and temperatures around $24^{\circ} \mathrm{C}$, but with the influence of cooler waters $\left(<19^{0} \mathrm{C}\right)$ in the bottom.

- The lowest abundances of ichthyoplankton was found in cooler $\left(21^{\circ} \mathrm{C}\right)$ and saline (35) waters subjected to coastal upwelling. However, a maximum in egg abundance occurred around Cabo de Santa Marta, where upwelling was less intense.

- Future studies should put effort in the identification of eggs and larvae of the species found in the present study in the region and on the measurement of surface current to be able to characterize the importance of physical processes to the ecology of fish eggs and larvae.

\section{ACKNOWLEDGEMENTS}

We thank colleagues of the Laboratório de Ecologia do Ictioplâncton (FURG) for their help. Financial support was provided by FINEPEDITAL CTINFRA 01/2001 (Proc. 23.01.0719.00). D.M.F was supported by CNPq/ PIBIC/FURG scholarship.

\section{RESUMO}

A abundância de ovos e larvas de peixes serve como um indicador do tamanho do estoque desovante, e a variabilidade nestes parâmetros está associada a flutuações no recrutamento de recursos pesqueiros. No sul e sudeste do Brasil a distribuição do ictioplâncton é influenciada pela dinâmica da Confluência Subtropical, pelo aporte de água doce e pela ação do vento na camada superficial do oceano. Este trabalho tem como objetivo descrever a distribuição de ovos e larvas de peixes ao longo da área compreendida entre Cabo Frio $\left(22^{0} 30^{\prime} S\right)$ e o Cabo de Santa Marta Grande $\left(28^{0} \mathrm{~S}\right)$, entre $15 / 11$ e 05/12/95. Em 85 estações foram coletadas amostras de plâncton com uma rede Bongo de $60 \mathrm{~cm}$ de diâmetro e $330 \mu \mathrm{m}$ de malha, dotada de fluxômetro e arrastada obliquamente. Salinidade e temperatura foram obtidas em cada estação com um CTD. O maior número de ovos e larvas de peixes e biovolume de zooplâncton foram encontrados em áreas distintas na região costeira, em temperaturas entre $23 \mathrm{e}$ $24^{\circ} \mathrm{C}$ e salinidades entre 33 e 34 . As larvas foram mais abundantes na costa de Santos; os ovos ao longo de Iguape; e, o biovolume de zooplâncton na região de Cananéia, sobrepondo-se, em parte, a distribuição de ovos de peixes. Os perfis verticais indicam que as maiores concentrações de ictioplâncton e de biovolume de zooplâncton ocorrem em águas estratificadas com menor salinidade e densidade e maior temperatura na camada superficial, e com águas mais frias e salinas nas camadas mais ao fundo, provavelmente devido à influência da Água Central do Atlântico Sul (ACAS). Nenhuma concentração significativa de ictioplâncton foi constatada na região de Cabo Frio. Ao longo do Cabo de Santa Marta Grande, foi observada uma grande concentração de ovos próxima à costa. Estes resultados demonstram uma atividade reprodutiva costeira das espécies de peixes localizadas ao longo desta região durante o período estudado.

\section{REFERENCES}

Andrade, H. A. (1996), Distribuição, abundância relativa e migração do Katsuwonus pelamis (Scombridae) em relação à temperatura superficial do mar e à dinâmica oceanográfica na costa SudesteSul do Brasil. Dissertação (Mestrado), Fundação Universidade do Rio Grande, RS.

Bakun, A. and Parrish, R. H. (1990), Comparative studies of coastal pelagic fish reproductive habitats: The Brazilian sardine (Sardinella aurita). J. Cons. Int. Explor. Mer., 46, 269-283.

Castello, J. P.; Duarte, A. K.; Möller, O. O.; Niencheski, L. F. H.; Odebrecht, C.; Weiss, G.; Habiaga, R. P.; Belloto, V. R.; Kitzmann, D.; Souto, C.; Souza, R. B.; Ciotti, A. M.; Filmann, G.; Schwingel, P. R. et al. (1990), On the importance of coastal and subantartic waters for the shelf ecosystems off Rio Grande do Sul. In: Watanabe, S. (ed.). II Simpósio de Ecossistemas da Costa Sul e Sudeste Brasileira: Estrutura, Função e Manejo. Publ. Aciesp, 74 : (1), 112-129. 
Castello, J. P.; Habiaga, R. P.; Amaral, J. C. and Lima Jr., I. (1991), Prospecção hidroacústica e avaliação da biomassa de sardinha e anchoita, na região sudeste do Brasil (outubro/novembro 1988). Publ. Esp. Inst. Oceanogr., (8), 15-29.

Castro, B. M.; Miranda, L. B. and Miyao, S. Y. (1987), Condições hidrográficas na plataforma continental ao largo de Ubatuba: Variações sazonais e em média scala. Bol. Inst. Oceanorg., 35 : (2), 135-151.

Castro, B. M. and Miranda, L. B. (1998), Physical oceanography of the western Atlantic Continental Shelf located between $4^{0} \mathrm{~N}$ and $34^{0} \mathrm{~S}$ coastal segment (4, w). The Sea, 11, 209-251.

Cury, P. and Roy, C. (1989), Optimal environmental window and pelagic recruitment success in upwelling areas. Can. J. Fish. Aquat. Sci., 46, 670-680.

Cushing, D. H. (1977), Marine ecology and fisheries. Cambridge University Press. 278 pp.

Frank, K. T. (1988), Independent distribution of fish larvae and their prey: natural paradox or sampling artifact? Can. J. Fish. Aquat. Sci., 45, 48-59.

Hempel, G. (1973), Fish egg and larval surveys. FAO Fisheries Technical Paper 122. 82 pp.

Hunter, J. R. and Alheit, J. (eds.) (1997), International Globec Small Pelagic Fishes and Climate Change program. Implementation Plan. Globec Report, 11, 1-36.

Katsuragawa, M and Matsuura, Y. (1992), Distribution and abundance of Carangidae larvae in the southeastern Brazilian Bight during 1975-1981. Bol. Inst. Oceanogr., 40 : (1/2), 55-78.

Katsuragawa, M.; Matsuura, Y.; Suzuki, K.; Dias, J. F. and Spach, H. (1993), O ictioplâncton ao longo de Ubatuba, SP: composição, distribuição e ocorrência sazonal (1985-1988). Publ. Esp. Inst. Oceanogr., (10), 85-121.

Kelley, D. E. (1997), Gri. A Program to Make Science Graphs. Version 2.1.10. 224p.

Lasker, R. (1975), Field criteria for survival of anchovy larvae: the relation between inshore chlorophyll maximum layers and successful first feeding. Fish Bull., 73 : (3), 435-462.

Matsuura, Y. (1979), Distribution and abundance of eggs and larval of the Brazilian sardine, Sardinella brasiliensis, during 1974-1975 and 1975-1976 seasons. Bull. Jap. Soc. Fish. Oceanogr., 34, 1-12.

Matsuura, Y.; Nakatani, K. and Tommasi, S. T. J. (1980), Distribuição sazonal de zooplâncton, ovos e larvas de peixe na região centro-sul do Brasil (19751977). Bol. Inst. Oceanogr., 29 : (2), 231-235.

Matsuura, Y. (1986), Contribuição ao estudo da estrutura oceanográfica da região sudeste entre Cabo Frio (RJ) e Cabo Santa Marta Grande (SC). Cienc. Cult., 38, 1439-1450.

Matsuura, Y. and Kitahara, E. M. (1995), Horizontal and vertical distribution of anchovy Engraulis anchoita eggs and larvae off Cape Santa Marta Grande in southern Brazil. Arch. Fish. Mar. Res., 42 : (3), 239-250.
Matsuura, Y. (1998), Brazilian sardine (Sardinella brasiliensis) spawing in the southeast Brazilian Bight over the períod 1976-1993. Rev. Bras. Oceanogr., 46 : (1), 33-43.

Miranda, L. B. and Katsuragawa, M. (1991), Estrutura térmica na região sudeste do Brasil (outubro/novembro de 1989). Publ. Esp. Inst. Oceanogr., 8, 1-14.

Muelbert, J. H. and Sinque, C. (1995), Processos oceanográficos e a distribuição de larvas de peixes na plataforma continental sul brasileira. 6. Congresso Latino Americano de Ciencias del Mar. Resumo. pp. 140.

Muelbert, J. H. and Sinque, C. (1996), Distribution of bluefish (Pomatomus saltatrix) larvae in the southern brazilian continental shelf. Mar. Freshwater Res., 47, 311-314.

Odebrecht, C. and Djurfeldt, L. (1996), The role of nearshore mixing on phytoplankton size structure off Cape Santa Marta Grande, southern Brazil (Spring 1989). Arch. Fish. Mar. Res., 43 : (3), 217-230.

Omori, K. and Ikeda, T. (1992), Methods in marine zooplankton ecology. Krieger Publishing Company Malabar. 332 pp.

Parrish, R. H.; Nelson, C. S. and Bakun, A. (1981), Transport mechanisms and reproductive success of fishes in the California Current. Biol. Oceanogr., 1 : (2), 175-203.

Resgalla Jr., C. and Montú, M. (1993), Associaciones de los indicadores hidrologicos en aguas del sur de Brasil ( $\left.31^{\circ} 40^{\prime} \mathrm{S}-33^{\circ} 45^{\prime} \mathrm{S}\right)$. 10. Simpósio Científico Tecnologico da Comision Tecnica Mixta del Frente Maritimo. Resumo. pp. 74.

Sinclair, M. and Iles, T. D. (1985), Atlantic herring (Clupea harengus) distribution in the Gulf of MaineScotian Shelf area in relation to oceanographic features. Can. J. Fish. Aquat. Sci., 42, 880-887.

Sinque, C.; Muelbert, J. H.; Ibagy, A. S. and Pacheco, L. M. (1996), Distribuição das larvas de Urophycis (PISCES-GADIDAE) nas regiões sudeste e sul do Brasil,no período de 1980 a 1991. 21. Congresso Brasileiro de Zoologia. Resumos. pp.144.

Soares, C. L.; Andreata, J. V. and Marca, A. G. (1991), Composição e sazonalidade do ictioplâncton da Laguna de Marapendi, Rio de Janeiro. Biotemas, $4:$ (2), 35-49.

Theilacker, G. H. (1980), Changes in body measurements of larval northern anchovy, Engraulis anchoita, and other fishes due to handling and preservation. Fish. Bull., 78, 685-692.

Received: May 27, 2002; Revised: December 27, 2002; Accepted: November 24, 2003. 